\title{
Stock market development and economic growth of Brazil, Russia, India, China and South African (BRICS) Nations: An empirical research
}

\author{
Sunday Ogbeide ${ }^{a}$ and Babatunde Akanji ${ }^{*}$
}

${ }^{a}$ Department of Accounting and Finance, Faculty of Social and Management Sciences, Elizade University, Ilara-Mokin, Ondo State, Nigeria

${ }^{b}$ Department of Human Resource Management, Faculty of Social and Management Sciences, Elizade University, Ilara-Mokin, Ondo State, Nigeria

\section{H R O N I C L E}

\begin{tabular}{l}
\hline Article history: \\
Received March 17, 2017 \\
Received in revised format May \\
112017 \\
Accepted June 202017 \\
Available online \\
June 212017 \\
\hline Keywords: \\
Real gross domestic product \\
Market capitalization \\
Turnover ratio \\
Total value of shares traded ratio \\
and inflation rate
\end{tabular}

\section{Introduction}

The acronym BRICS connotes Brazil, Russia, India, China and South Africa. It was first coined out by Jim O'Neil in 2001 when he examined the subject - "Building better global economics" in selected emerging countries which were seen to be the largest emerging markets of a different nature. According to Global Sherpa (2009), formulation of BRICS bloc is to foster cooperation with a view to overcoming certain challenges peculiar to those faced by other emerging economies. A 2005 report of Goldman Sachs, a leading global investment bank headquartered in New York placed the BRICS countries consistently in the top half of the global rankings, among the best environments for sustained economic growth. Since its inception, the BRICS concept has been founded on economic growth projection with 
no relevance to other parameters such as political and/or social development inclusivity, let alone sustainability as these dimensions are entirely neglected by Gross Domestic Product (GDP) earnings. It therefore follows that the only uniting factor is the scale of their economies in terms of GDP and their sustained growth rates. As such, these countries are as a matter of all intents and purposes, a "GDP Club" (Ahn \& Cogman, 2007).

However, one of the difficulties of examining cross-section studies on like in the case of BRICS countries may be the fact that each of the countries has varying stock market strength, corporate governance structure, political climate, investment climate and much more economic conditions. Overtly, BRICS countries are being recognized to play significant role at influencing the world economy. They have been predicted to overtake the G-7 countries in the nearest future because of the relationship between their stock markets and growth of the economies (O'Neil, 2001). However, the size and performance of the stock market in the individual BRICS country differ markedly. Stock market in Brazil for instance is a little developed, has low capitalization, non-significant business volume, few initial offerings, reduced the number of public companies, transactions highly concentrated in few shares and low liquidity (Leal, 2008).

Most researches have always considered the nexus between stock market development and economic growth on individual country basis with varying variables, times series, econometric models and methods of the data analysis. No studies have robustly examined the subject matter in cross-countries. The empirical results from the individual country study have always been mixed and inconclusive. The studies in each of the BRICS' countries also appear to have inconclusive empirical results. Matos (2003) using quarterly data from the period 1980-2002 and the Granger Causality Test, found significant evidences of the bidirectional effect between stock market development and economic growth in Brazil. Russia stock market over the years has been buffeted by certain factors like socioeconomic and political factors. These factors have interplayed to impinge on the growth of the economy. Mehrabani (2012) states that there is a disagreement if the development of stock market occurs from the economic growth or if it is the opposite in Russia. As a result, the findings show that the market capitalization and liquidity did not positively influence the growth of the economy, thus serving as a further ground for empirical investigation. Kamat and Kamat (2007) empirically examined the relationship between stock market development indicators and economic growth in India. The study found stock market size was positively associated with economic growth. The study further revealed there was no support for the association between stock market liquidity and economic growth in India. Agrawalla and Tuteja (2007) confirmed a stable long run equilibrium relationship between stock market developments and economic growth.

Ruyong (1999) points out that during the period 1994 - 1998, China's stock market development have little or no effect on the economic growth. Wang (2002) using China's stock market quarterly data in a regression model discloses that market liquidity has limited effect on economic growth. MuQuing et al. (2001) report that stock market capitalization rate, the stock market turnover and stock market trading rate as indicators with the use of quarterly data which has not significantly impacted on the growth of China's economy. Similarly, Zhao (2002) ascertain that there is only a weak negative correlation between Chinese stock market and capitalization rate, while there is a positive relationship between trading value and turnover rate of economic growth. Ndako (2008) examines the casual relationship between stock markets, banks and economic growth in South Africa using quarterly time series data from 1983 to 2007; the paper uses Vector Error Correction model (VECM) based causality tests to establish a link between stock market development and economic growth. The empirical investigation suggests that in the long-run, there is an evidence of bidirectional causality between stock market development and economic growth.

From the foregoing, it has been established that there is a little or no study that have empirically determine how stock market development engenders the economic growth of the BRICS nations in a unified manner. Hence, this study is undertaken in this direction. Thus, an evaluation of extant literature 
on the association between stock market development and economic growth in BRICS is undertaken in this study while the empirical result of this paper shall be obtained through the econometric analysis of pooled data of the individual BRICS countries.

\section{Literature review}

By the 1970s, Brazil became the leading economy in Latin America due to its industrialization, natural resources and large labor pool. Brazil is the eight largest economy in the world (Clemente et al., 2012). The stock market plays a key role in its economic development. For instance, the stock market of Brazil constitutes an efficient mechanism for allocating resources. Historically, a long period of high inflation rate and general economic instability exerted serious negative effects on the Brazilian stock market until the mid-1990s (Clemente et al., 2012). The Brazilian stock market fostered by the economic and political stability appeared to have initiated what could be described as a vigorous pattern of growth since 2003; and this is followed by an intense inflow of capital from abroad. This engendered the core of the growth process in the country.

On the empirical fronts, many studies have examined the nexus between stock market development and economic growth in Russia. El-Wassal (2005) investigates the impact of stock market development using indicators such as market capitalization, turnover ratio and value of shares traded on the economic growth of Russia for the period 1996-2010 on quarterly basis. The result shows that market capitalization did not significantly influence the economic growth of Russia but turnover ratio and value of shares improved it, though they were not statistically significant. Garcia and Liu (1999) ascertain the relationship between stock market development and economic performance of Russia using time series data for the period 2000-2008 on monthly basis. The result reveals that stock market development positively enhanced the Russian economic growth. In addition, Olfa (2007) investigates the impact of certain stock market development on the growth of Russian economy. The results reveal that stock market enhances the growth of the economy and conclusions drawn is that the government needs further reform of the stock market and needs to further strengthen the legal environment to encourage inflow of foreign direct investment. In addition, Dailami and Aktin (1990) find that a welldeveloped stock market can enhance savings and provide investment capital at lower cost by offering financial instruments for savers to diversify their portfolios in Russia.

The causal nexus between stock market development and economic growth was examined by Vazadikis and Adamopoulos (2009) in Russia and found that there was a positive association from economic growth to stock market development and at the same time interest rates had a negative effect on stock market development. Additionally, Brasoveanu et al. (2008) study the correlation between capital market development and economic growth in Russia for the period 2000-2006. Their results reveal that stock market development was positively correlated with economic growth by way of feedback effect. However, the strongest link is from economic growth to capital market, signifying that stock market development follows to economic growth. In a similar vein, India has adopted modern strategies to promote its stock market development since the late 1970s and this has become more sophisticated after the introduction of economic reforms of 1991. These reforms brought expansion in terms of the number of listed companies, number of shareholders in the market and market capitalization (Sudharshan \& Rakesh, 2011). As noted by Nagashi (1999), this has resulted in India to become one of the most active and leading market among all developing countries of the world. Sinha and Macric (2001)'s study indicate that there was a positive and statistically significant relationship between the income and financial variables for India. In addition, Kamat and Kamat (2007) explore the nexus between stock market development and economic growth for India for the period of 19712004 and their results support the proposition that stock market development stimulate economic growth in the short-run. 
Acharya et al. (2009) examined the nexus between stock market development and economic growth in Indian states for the time span of 1981- 2002 and found a long-run relationship between stock market development and growth across Indian state. Similarly, Agrawalla and Tuteja (2007) find that stable long-run equilibrium relationship exists between stock market development and economic growth in case of India. Further, Deb and Mukherjee (2008) test the causal nexus between stock market development and economic growth for Indian economy for the period 1996-2007 by using quarterly data on real GDP, real market capitalization ratio and stock market volatility. Their study find a strong causal flow from the stock market development to economic growth and stress that there was a bidirectional relationship between market capitalization and economic growth. So local investors were not permitted to trade B shares in China. As noted by Wang and Ajit (2013), despite the capital market segmentation, the stock market has developed quickly and is becoming an indispensable part of China's financial infrastructure. Wang (2002) also argues that there was no obvious correlation between China's capital market development and economic growth. Wang and Ajit's (2013) study showed that the relationship between stock market development aided by total market capitalization and economic growth is negative in China. Duan et al. (2009) examine the relationship between stock market development and economic growth in China using data set for the period 1995-2007. They apply the co-integration and causality analysis technology. The result obtained provides no evidence of a positive and significant causal relationship going from stock market development to economic growth in China. Moreover, the result indicates that stock market promotes economic growth in China by mobilizing savings and providing liquidity. However, Ru-yong (1999) pointed out that during the period 19941998, China's stock market development had little effect of economic growth. Thus, Zheng et al. (2000) argue that the improvement of China's stock market liquidity is not to promote household savings but for the conversion of savings to investment, which may have effect on economic growth. Zhao (2002) also found that there was only a weak negative correlation between Chinese stock market and capitalization rate, while there is a positive relationship between trading value and turnover rate of economic growth.

Chipaumire and Ngirande (2014) ascertained how stock market liquidity affects economic growth in South Africa. They conclude that stock market liquidity impact growth in South Africa. Using quarterly time series data from 1983-2007, Ndako (2008) examines the relationship between stock markets; banks and economic growth in South Africa using vector error correction model and found that shared that stock market development impacted significantly on the economic growth of South Africa. This robust positive finding may intuitively be linked to the developing nature, size and reform of the South African's financial system.

\section{Methodology}

This study employed a longitudinal research design. BRICS countries are taken as samples for the period 1994-2014. Data for the study was generated from World Bank Indicators (various issues), particularly from 1994 to 2014. The study employs inferential statistics for the purpose of data analysis. While the inferential statistics however include the dynamic panel estimation generalized least square bivariate method, encompassing Panel fixed/ random effect.

\subsection{Model specification}

The mathematical form of the regression model used in this study is:

$$
R G D P G R=\mathrm{F}(\mathrm{MCAP}, \mathrm{TVSTR}, \mathrm{TR} \text { and INFR) }
$$

It is stated in stochastic form as:

$$
\text { RGDPGRit }=\beta_{0}+\beta_{1} M C A P_{i t}+\beta_{2} T R_{i t}+\beta_{3} T V S T R_{i t}+\beta_{4} I N F R_{i t}+\mu_{i t}
$$


where

$\beta_{1}$ to $\beta_{4}$ represents coefficient of the parameters of estimation

$i$ represents cross- section, i.e individual countries of BRICS and $t$ is the period in question.

$R$ GDPGR real GDP growth rate

MCAP represents market capitalization

TR represents turnover ratio

TVSTR represents total value of traded ratio

Inflation represents core inflation rate.

Apriori expectations are $\beta_{1}$ to $\beta_{4}>0$. This implies the independent variables are expected to positively influence stock market development in BRICS under the period observed and in accordance with the underlying theoretical framework.

\subsection{Empirical analysis}

Table 1

Summary of unit root

\begin{tabular}{llll}
\hline Variables & ADF test at level & Critical statistic value at 5\% & Meaning \\
\hline RGDPGR & -3.409733 & -2.867066 & Stationary at level \\
MKT CAP & -17.40610 & -2.867112 & Stationary at first difference \\
TVSTR & -3.090406 & -2.867078 & Stationary at level \\
TR & -4.678361 & -2.867089 & Stationary at level \\
INFR & -5.826216 & -2.867066 & Stationary at level \\
\hline
\end{tabular}

Source: Author's Computed from E-view 8.0

The unit root test of the time series for BRICS shows that some of the variables were stationary at levels while others were stationary at first difference. For example, Table 1 reveals that RGDPGR, TR and INFR were stationary at level; while MKTCAP and TVSTR are stationary at first difference at 5\% significant level. This explains that the existence of unit root among the variables cannot be accepted.

Table 2

Diagnostic tests result

\begin{tabular}{lll}
\hline Variance inflation factors (VIFs) & & \\
\hline VARIABLES & Uncentered VIF & Centered VIF \\
MKTCAP & 1.64 & 1.38 \\
TVSTR & 2.11 & 6.98 \\
TR & 21.79 & 6.82 \\
INFR & 0.03 & 1.29 \\
\hline Breusch - Godfrey - serial correlation LM test & & \\
\hline F-statistic $=13.64$ & Prob. F $(2,18)$ & 0.0002 \\
Obs * R-squared = 15.06 & & Pro. Chi-square (2) 0.765 \\
\hline Heteroskedasticity test Harvey & & \\
\hline F-statistic 0.34 & Prob. F $(4,20)$ & 0.84 \\
Obs * R-squared 1.60 & Prob. Chi-square $(4)$ & 0.80 \\
\hline Ramsey Reset Test & & \\
\hline t-statistic $=2.38$ & Df $=19$ & 0.02 \\
F-statistic $=5.67$ & Prob. F $(1,19)$ & 0.02 \\
\hline
\end{tabular}

Source: Author's computation from E-views 8.0 version (2016) 
The diagnostic results in Table 2 shows that the variance inflation factor statistic is less than 10 (centered VIF < 10) for each of the variables. This indicates absence of multicollinearity among the explanatory variables. The ARCH (Harvey) for heteroscedasticity test shows the presence of homoscedasticity $(0.84>0.05)$, thus confirming the constant variance assumption of the ordinary least square estimator. The Breusch-Godfrey serial correlation LM test result of $0.765>0.05)$ points out the absence of higher order correlation. The Ramsey Reset Test result of $(0.02>0.05)$ substantiate validity of the regression model.

Pooled Least Squares

Fixed Effect Model Regression Equation

$\mathrm{RGDPGR}=0.470 \mathrm{C} \quad-0.030 \mathrm{MKTCAP} \quad-0.111 \mathrm{TR}+0.368 \mathrm{TVSTR}-0.042 \mathrm{INFR}$

$\begin{array}{lllll}(7.911) & (-4.094) & (-10.181) & (16.203) & (-3.130) \\ (0.000) & (0.000) & (0.000) & (0.000) & (0.001)\end{array}$

R-squared $=0.1612$

Adjusted R-squared $=0.1596$

F-statistic $=100.66$

Prob $($ F-statistic $)=0.000$

Durbin Watson statistic $=1.55$

Source: Computed from E-view 8.0

Cross country analysis of BRICS was quite commendable judging with the F-statistic value of 100.66 of the pooled least square model with a common constant across sections. Overall, the model is significant at the parsimonious $1 \%$ level indicating that the regression jointly explained fluctuation in the regressand. All estimated coefficients were significant at $1 \%$ level and wrongly signed except TRVSTR. Particularly, MKTCAP and TR reduce real GDP growth rate among the group (BRICS) while TRVSTR and INFR promote unit increases in MKTCAP and TR will reduce real GDP growth rate by $0.03 \%$ and $0.11 \%$ respectively whereas unit increases in TRVSTR and INFR will raise real GDP growth rate by $0.36 \%$ and $0.04 \%$ respectively ceteris puribus. This result shows that capital market activities operation were not adequate to boost or enhance growth rate of real GDP. From this development, other estimating techniques may be considered for robustness and to ascertain the adequacy and influence of the capital market on growth rate of real GDP among member nations of BRICS other power data estimation techniques that can come in handy are the fixed- effect and random -effect models. However, Hausman test needs to be conducted to inform a choice of a more appropriate technique to adopt between the fixed or random earlier mentioned.

\subsection{Presentation of Hausman test result}

The Hausman test statistic is employed to test for the erogeneity of the unobserved error component. The test is necessary because the random effect needs to be uncorrelated with the explanatory variables; otherwise, there is endogeneity problem and the random problem effect estimator will be inconsistent.

Table 3

Hausman Test Result

\begin{tabular}{lllll}
\hline Test Summary & Chi-Square Statistic & Chi-Sq. d. f. & Prob. \\
\hline Cross section random & 3206.93 & 4 & 0.0000 & \\
Cross section random effects test comparisons: & Fixed & & & \\
\hline Variable & -0.229 & Random & Var(Diff.) & Prob. \\
\hline MKTCAP & -0.341 & -0.030 & 0.0000 & 0.0000 \\
TR & 0.288 & 0.368 & 0.0000 & 0.0000 \\
TVSTR & -0.092 & 0.042 & 0.0002 & 0.0000 \\
INFR & & & 0.0000 & 0.0000 \\
\hline Source: Computed from E-view 8.0 & & & &
\end{tabular}


The null hypothesis for the Hausman test is: $\mathrm{H}_{0} \beta_{R E}=\beta_{F E}$. Where $\beta_{R E}$ and $\beta_{F E}$ are coefficient vectors of the time-varying explanatory variables excluding the time variables. Thus, if null hypothesis is rejected, the conclusion simply that can be drawn is that random effect (RE) model is inconsistent; and the fixed effects (EF) model will be preferred. Therefore, the Hausman test result of our model is presented in Table 3.

An observation of the conducted Hausman's test for this study suggests that the fixed effect model is preferable. This decision is based on the significance of the estimated very large chi-square statistic value of 3206935090 , which is highly significant at the $1 \%$ level implying a rejection of the null hypothesis in favor of the fixed effect model.

\section{Fixed Effect Model Regression Equation}

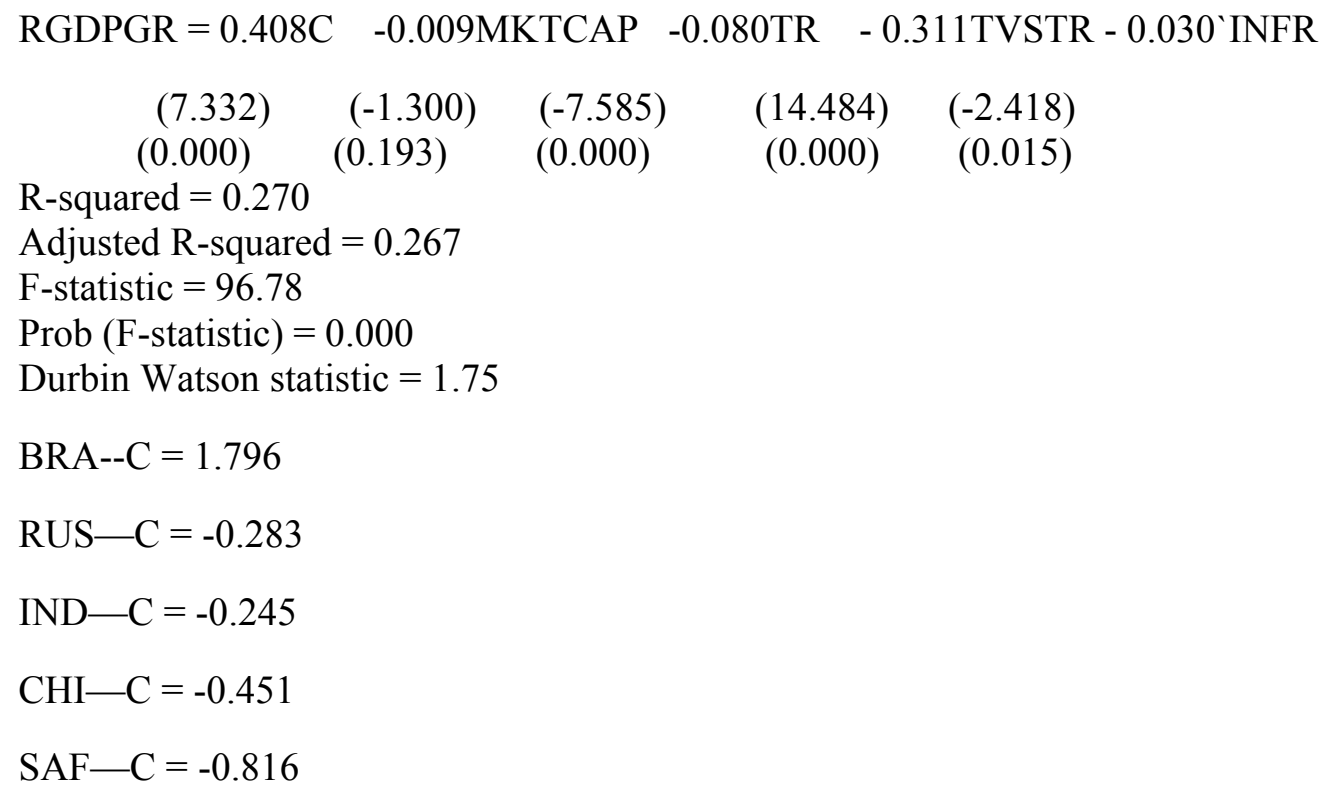

Source: Author's computations from E-view 8.0

Result of the estimated fixed-effect model is quite good and highly significant following the probability value (0.00) of the F-statistic, which validates the overall importance of the model. The fixed crosssectorial constant term, and TVSTR were highly significant at $1 \%$ level; INFR was significant at 5\%. Again, all estimated coefficient are wrongly signed except that of TRVSTR. Average growth rate of real GDP growth rate among member countries of BRICS stood at approximately $41 \%$ per period. Brazil, Russia and India have positive growth rate of real GDP while China and South Africa have a negative growth rate on average over the period. Particularly, Brazil has the highest among the group while South African has the least. Brazil's growth rate of real GDP has above the group's average by $179 \%$ and India, which is second, has an average of $24.5 \%$ less than group's average. Russia (third), China (fourth) and South Africa (fifth) all have average growth rate of real GDP below the group's average by $28.3 \%, 45 \%$ and $81.6 \%$ respectively,

Basically, this is a reflection of the extent to which capital market operations influence the growth rate of economic activities in these countries. On average, a unit increases in MKTCAP and TR variables will hinder growth rate of real GDP in BRICS by $0.01 \%$ and $0.08 \%$ respectively. This is a clear indication that members of this group need to further develop their capital markets in order for them to adequately drive economic growth. On the other hand, TRVSTR and INFR both have a positive influence on real GDP growth in BRICS on the average. Specifically, unit rises in TRVSTR and INFR would raise growth of real GDP in BRICS by $0.31 \%$ and $0.03 \%$ respectively. INFR positive impact on growth rate of real GDP in BRICS may be attributed to investors- domestic and foreign confidence in 
the economies of the group. In all, we can deduce that capital market operations in BRICS significantly impact on real GDP growth rate or economic expansion.

\section{Discussion of Findings}

The BRICS have had fair share from the global financial crisis recently. Nonetheless, stock market activities have continued unabated but in different dimension among the BRIC. The need to examine the performance of the BRICS in relation to how the stock market influences the economy was the primary goal of this study. The empirical estimation from the analysis above shows that stock market development contributed to the real GDP growth rate of the BRICS nations. The turnover ratio of the BRICS though negatively affected the economies of the individual nations, was however found to increase the GDP of these economies significantly. It has also been proven that the turnover ratio as indicator of the depth of stock market deepened considerably over the years in the BRICS (O'Neil, 2001). The indicator pumped from a risen base of $115.9 \%$ in China to $229.6 \%$, almost in the past two decades. Brazil and South Africa have also witnessed a significant increase in the ratio from 2009. Except during the global financial crisis where the activities of the stock market were barely on the increase in the BRICS, the stock market did extra-ordinarily well. This could be attributed to the integration of the BRICS financial market with world financial markets where there was a combine external financing of stock market from bonds, equities and loans. These have resulted to high proliferation of investment and thus causing increase in BRICS GDP. The study finding further supports the prediction of O'Neil that the combined economies of the BRICS group could overtake that of U.S and European Union bodies in the next few decades.

The market capitalization of the BRICS was observed to significantly improve the real GDP growth rate. The finding could be adduced to influx of direct and portfolio investment. China's share of global market capitalization has grown astronomically, to the extent that it is being predicted that it is likely to overtake the US in terms of stock market capitalization by 2030. This obvious positive prediction is not farther from the expanding investment and high economic growth in China. Possibly, this has a way of reducing the weakness of other BRICS member states and then strengthens their position with regard to GDP. On the whole, it can be summarized that stock market development impact significantly on the economic growth of the BRICS.

\section{Conclusion and recommendation}

This study particularly examined the stock market development economic growth of BRICS - Brazil, Russia, India, China and South Africa. The study ascertained that stock market development exerts significant long-run impact on the economic growth of BRICS. This may not be unconnected with the nature of data used, variable measurement, period observed, economic policies, differential and kind of corporate governance in the stock market of the countries. Overall, the general empirical findings are in tandem with the theoretical frameworks that underpinned this paper.

From the empirical findings, the study recommends that to engender the attainment of the GDP growth rate desired by the member countries of the BRICS, there has to be policy implementations that will enhance the supply of securities investment. This will stimulate trade in stocks and increase the stock market development. To enhance the growth and development of the emerging markets, the markets must encourage the development of more specialized funds such as pension funds and mutual funds and securities such as derivatives. This is so because these collective investments and securities have the propensity to cause increase in the demand for securities, thus enabling the market to generate more capital, improve its depth and liquidity. Generally as these funds and securities grow, the size of the market (market capitalization) increases, and may influences the liquidity of stocks and the economy at large. South Africa inclusivity into the BRICS GDP club and not yielded much contribution. So policies in South Africa should be geared towards stimulating its comparative contribution by rapidly growing its economy. Moreover, the weaknesses of each of the BRICS member country should be 
taken as policy focus and strategies necessary to strengthen them should be swiftly applied. If these suggestions are considered by the government of these emerging countries, the chances are that the stock market will be highly stimulated; lead to economic enhancement and ultimately to the attainment of the prediction that the BRICS will overtake the G-7 economies by 2027 (Leal, 2008).

\section{References}

Acharya, D., Amanulla, S., \& Joy, S. (2009). Financial development and economic growth in Indian states: an examination. International Research Journal of Finance and Economics, 24(2), 117-130.

Agrawalla, R. K., \& Tuteja, S. K. (2007). Causality between stock market development and economic growth: a case study of India. Journal of Management Research, 7(3), 158.

Ahn, J., \& Cogman, D. (2007). A quiet revolution in China's capital markets. McKinsey on Finance, 24, 18-24.

Agrawalla, R. K., \& Tuteja, S. K. (2007). Causality between stock market development and economic growth: a case study of India. Journal of Management Research, 7(3), 158.

El-Wassal, K. A. (2005). Understanding the growth in emerging stock markets. Journal of Emerging Market Finance, 4(3), 227-261.

Brasoveanu, L. O., Dragota, V., Catarama, D., \& Semenescu, A. (2008). Correlations between capital market development and economic growth: The case of Romania. Journal of applied quantitative methods, 3(1), 64-75.

Chipaumire, G., \& Ngirande, H. (2014). How stock market liquidity impact economic growth in South African Journal of Economics, 5(2), 185-192.

Clemente, A., Taffarel, M., \& Espejo, R. A. (2012). The Brazilian Stock Market-Dimension, Structure, and Main Features. Business Dynamics in the $21^{\text {st }}$ Century, 221.

Dailami, C., \& Aktin, G. (1990). Stock markets in developing countries: Key issues and a research agenda, policy research and external affairs. Working papers. The World Bank.

Deb, S. G., \& Mukherjee, J. (2008). Does stock market development cause economic growth? A time series analysis for Indian economy. International Research Journal of Finance and Economics, 21(3), 142-149.

Duan, W., Gu, B., \& Whinston, A. B. (2009). Informational cascades and software adoption on the internet: an empirical investigation. Mis Quarterly, 33(1), 23-48.

El-Wassal, K. A. (2005). Understanding the growth in emerging stock markets. Journal of Emerging Market Finance, 4(3), 227-261.

Garcia, V. F., \& Liu, L. (1999). Macroeconomic determinants of stock market development. Journal of Applied Economics, 2(1), 29-59.

Global Sherpa. (2009). Accessed from http://www..globalsherpa.org/bric-countries-brics on 29/01/2017.

Kamat, M. S., \& Kamat, M. M. (2007). Does financial growth lead economic performance in India? Causality-cointegration using unrestricted vector error correction models. MPRA paper No. 6154, pp. $1-26$.

Leal, A. R. (2008). How will the EU approach the BRIC countries. Future Trade Challenges, 2(4).

Matos, O. C. (2003). Inter relacoes entre desenroluimento. Financeiro, export acoes, e. cresamento economico: Analyse da experience brasilera. Notas tech leas do Banco cental to Brazil, n 4o, Bra silia.

Mehrabani, F. (2012). Corporate Governance, Iran Stock Market andEconomic Growth. International Journal of Trade, Economics and Finance, 3(5), 370.

MuQuing, M., Robert, A., \& Chang, L. (2001). An empirical study on the relationship between stock market index and the national economy: The case of China. International Journal of Finance, 4(1), $13-31$.

Nagashi, M. (1999). Stock market development and economic growth: Dubious relationship. Economic and Political Weekly, 34(29), pp. $2004-2012$. 
Ndako, U. B. (2008). Financial development, Economic growth and stock market volatility: Evidence from Nigeria and South Africa. Australian Journal of Business and Management Research, 2(2), pp. $20-30$.

O’Neil, J. (2001). Building better global economic BRICS. Goldman Sachs global economic paper No. 66.

Olfa, C (2007). Overreaction effect in the Tunisian stock market. Journal of Asian Business Strategy, 8(2), pp. 134-140.

Ruyong, T. (1999). An empirical research on the relationship between China's financial development and economic growth. Economic Research Journal, 10(2), 18 - 37.

Sinha, D. \& Macric, J. (2001). Financial development and economic growth: The case of Eight Asian countries. Economic - Internazionale, 54(2), 219 - 234.

Sudharshan, R.P., \& Rakesh, G. (2011). An empirical analysis of stock market performance and economic growth: Evidence from India. International Research Journal of Finance and Economic, $7(3), 1-15$.

Vazadikis, A., \& Adamopoulos, A. (2009). Stock market development and economic growth. American Journal of Applied Sciences, 6(11), 1933 - 1941.

Wang, B., \& Ajit, D. (2013) Stock market and economic growth in China. University of Northern British Columbia, Prince George, British Columbia, Canada.

Wang, E. (2002). The theoretical analysis on the relationship between China's capital market and economic growth. China Economist, 2, 1 - 10.

Wang, S. S., \& Li, W. (2004). Information diffusion, transaction costs, and the performance of technical trading rules in the emerging stock market in China, EFMA 2004 Basle Meetings Paper. Available at www.ssm.com/abstract $=487783$ accessed on $03 / 01 / 2017$.

Zhao, C. S. (2002). Corporate governance, stock market and economic growth in Brazil. Corporate Ownership \& Control, 6(2), $222-237$.

Zheng, J., Yuan, G. \& Hu, Z. (2000). An empirical study on the connection between China's stock market and economic growth during the transforming period. Management world, 6, $15-24$.

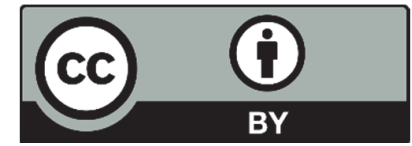

(C) 2017 by the authors; licensee Growing Science, Canada. This is an open access article distributed under the terms and conditions of the Creative Commons Attribution (CC-BY) license (http://creativecommons.org/licenses/by/4.0/). 